\title{
IMPACT OF USING DIFFERENT LEVELS OF DRIED POMEGRANATE BY- PROUDUCTSAS FEED ADDITIVES ON PERFORMANCE OF GROWING BARKI LAMBS
}

\author{
Randa R. El-Elaime \\ Department of Animal Production, Faculty of Agriculture, Cairo University, Egypt.
}

\author{
(Received 12/1/2021, accepted 9/3/2021)
}

\section{SUMMARY}

$\mathrm{T}$ The present study was conducted to investigate the impact of adding different levels of dried Pomegranate by-products (DPB):10g/head /day (R2), 20g/head /day (R3), 30g/head /day (R4), versus an supplemented ration (R1) control ration which consists of $70 \%$ concentrate and $30 \%$ alfalfa hay without any additives) on growth performance, blood parameters, feed efficiency and economical efficiency of twenty growing Barki lambs (averaged 5-6months old and weighed on average $28 \mathrm{~kg}$ ) in the growth trial(120 days ). Twelve adult rams (weighed $42 \mathrm{~kg}$ ) were used in digestion trials to estimate nutritive values, digestion coefficient, some rumen parameters. The Results could be summarized as follows: Pomegranate by-products contained numerous active metabolites such linalool, myrcene, menthol and thymol. The DPP contained 380, 149, 71, 172 and $65 \mathrm{mg} / 100 \mathrm{~g}$ of Ca, P, Na, K, and $\mathrm{Mg}$, respectively. Also, it contained $\mathrm{Se}, \mathrm{Fe}$, and $\mathrm{Zn}$ respectively. Moreover, it contained vitamin $\mathrm{C}$; vitamin E, vitamin A, vitamin B 1 and vitamin B2. Adding different levels of dried Pomegranate byproducts (DPB):10g/head /day ( R2), 20g/head /day ( R3), 30g/head /day ( R4), improved all nutrients digestibility (DM, OM, CP, CF, EE and NFE) and nutritive values as TDN, DCP compared with control ration. The highest significant $(\mathrm{P}<0.05)$ values were found with lambs fed ration containing $20 \mathrm{~g} /$ head/day of DPB (R3) followed by $10 \mathrm{~g} /$ head/day of DPB (R2) compared to the control group. Also, adding different levels of dried Pomegranate by-products (DPB) improved the blood parameters .Pomegranate by-products decreased cholesterol level in plasma, with the highest effect for R3 followed by R2 and R4 compared to the control group. Moreover, Pomegranate by-products significantly $(\mathrm{P}<0.05)$ decreased total lipid and increased total plasma protein and globulin comparing with the control group. Additionally, Pomegranate by-products significantly $(\mathrm{P}<0.05)$ improved the daily gain by175.8 $\mathrm{g}, 175 \mathrm{~g}$ ,158.3g for R2, R3, R4, respectively compared to the control group by $150 \mathrm{~g}$.Also, Pomegranate byproducts significantly $(\mathrm{P}<0.05)$ increased the economic efficiency for growing lambs. The effect was the highest for R2 and R3 followed by R4 compared to control group. Referring to the obtained results, it could be recommended that adding 10-20 g / head /day of dried Pomegranate by- products in growing lambs ration exhibited positive effect on productive performance of Barki lambs, weight gain, feed efficiency and economic efficiency, and decrease plasma cholesterol and total lipids.

Keywords: Dried Pomegranate by-products, Performance, digestibility, feeding values, blood parameters economic efficiency and lambs.

\section{INTRODUCTION}

Pomegranate (Punica granatum L.) has several of active components, like phenolic acids, tannins and flavonoids. This numerous active components are the main reason for its high health benefits and antioxidant .

Pomegranate pulp consists of diverse proportions of seeds, peel, and residual pulp. These by-products produced by extraction of pomegranate juice. Pomegranate pulp consists of crude protein, fiber, and fat makes this by-product an appropriate feed to be included within the diet of ruminants. Lately, by-products of Pomegranates, practically pomegranate peel extract, are increasing attention due to its therapeutic properties such as antioxidant, antimicrobial, anticancer and anti-inflammatory activities. (Omer et al., 2019 and Chen et al., 2020).

Shabtay et al. (2008) illustrated that pomegranate peels enhanced a significantly $(\mathrm{P}<0.05)$ increased feed intake and weight gain in calves. 
Also, Sadqet al. (2016) demonstrated that adding different levels $(0,1,2$, or $4 \%)$ of pomegranate peels to lambs rations enhanced growth performance of these lambs.

Pomegranate was previously reported to own antioxidant activity (Khalaf, Arafat et al., 2019; Bakeeret al., 2021). Pomegranate peels were found to have overwhelming antioxidant properties than pomegranate juice (Zeweil et al., 2013, Bakeer et al., 2021).

Therefore, present study aimed to investigate the impact of using different levels of dried Pomegranate by- products on nutrient digestibility, feeding values, blood parameters and lambs growth performance. Also, the economic efficiency of the experimental rations was calculated.

\section{MATERIALS AND METHODS}

\section{Determination of essential oils, Vitamins and Minerals in Pomegranate pulp: \\ Determination of essential oils in Pomegranate pulp:}

From sample of $400 \mathrm{gm}$, triplicates, each of air dried Pomegranate by-products were separated by water distillation for 5-6 hr .According to the method of Guenther (1961). Analysis of the oil was carried out using GLC chromatography. Analysis of the oil was applied using GLC chromatography equipped with a FID detector.

\section{Determination of Vitamins in Pomegranate pulp:}

Vitamins including B1, B2, vitamin C, vitamin A and vitamin E of DPP were determined using highpressure liquid chromatography (HPLC) according to Leth and Sondergaro (1983) and AOAC (2005).

\section{Determination of Minerals in Pomegranate pulp:}

Calcium, P, K, Na, Mg, Fe, and Se were determined by Atomic Absorption Spectrophotometers according to AOAC (2005). Phosphorus was analyzed with N-4C method according to (Kraul 1966). Moreover, selenium was determined with an auto- analyzer fluoro-metric method according to Brown and Watkinson (1977).

\section{Feeding Trials:}

\section{Experimental animals:}

Twenty growing Barki lambs (average 6 months old and weighed in average $28 \mathrm{~kg}$ ) were randomly divided into four similar groups (five animals each) according to their body weight. Lambs were weighed every two weeks right before morning feeding through the experimental period which lasted for 120 days to record any change in body weight and to adjust their feed intake according to their changed nutrients requirements (NRC, 2007).

\section{Experimental rations:}

All animals were fed on the control ration that consisted of $30 \%$ alfalfa hay and $70 \%$ concentrate feed mixture (CFM), respectively. Concentrate feed mixture (CFM) consisted of yellow corn grain $42.9 \%$, wheat bran $30.7 \%$, soya bean meal $21.4 \%$,common salt $1 \%$,

Di-calcium phosphate $1.5 \%$, minerals and vitamins mixture $2.5 \%$.

The experimental groups were fed on:

R1 (Control Ration) without adding Pomegranate pulp.

R2 (Control Ration $+10 \mathrm{~g}$ Pomegranate $\mathrm{pulp} / \mathrm{h} /$ day).

R3 (Control Ration +20 g Pomegranate pulp /h / day).

R4 (Control Ration +30 g Pomegranate pulp /h / day).

Water was available all time. Fresh Pomegranate by-products containing peel, pulp and seeds were collected from plant of food industry and shipped for sun drying to produce DPB. Lambs in all groups were received their nutrient requirements according to NRC,( 2007) twice daily at 8-am and 3 -pm .

The chemical analysis of the experimental rations was determined according to AOAC (1996) at the laboratories of Animal Production Department, Faculty of Agriculture, Cairo University. 
Egyptian J. Nutrition and Feeds (2021)

Chemical analysis of feed ingredients and experimental rations are illustrates in Table (1).

Table (1): Chemical analysis of feed ingredients and experimental rations, on DM basis.

\begin{tabular}{llllllll}
\hline Item & \multicolumn{7}{c}{ Chemical composition \%, on DM basis } \\
\cline { 2 - 8 } & DM & OM & CP & CF & EE & NFE & Ash \\
\hline Alfalfa Hay & 90.00 & 89.00 & 15.10 & 25.00 & 2.50 & 46.40 & 11.00 \\
Dried Pomegranate pulp & 94.80 & 93.22 & 7.43 & 10.42 & 2.74 & 72.63 & 6.78 \\
Yellow corn & 90.00 & 90.50 & 8.00 & 2.60 & 4.00 & 75.90 & 10.50 \\
Soya bean & 91.50 & 91.10 & 42.00 & 4.00 & 2.00 & 43.10 & 8.90 \\
Wheat bran & 89.60 & 91.60 & 11.91 & 9.30 & 2.42 & 67.97 & 8.40 \\
Experimental Rations & 89.60 & 89.80 & 15.79 & 10.88 & 2.77 & 60.36 & 10.20 \\
\hline
\end{tabular}

\section{Digestibility Trials:}

\section{Feeds and feces sampling and analysis:}

Twelve adult rams (weighed $42 \mathrm{~kg}$ ) were used in 21 days digestion trials (3 for each group), consisting of 14 days as preliminary period, and 7- days as collection period. Animals were kept in metabolic cage and fed $90 \%$ of their rations, which provide their maintenance requirements (NRC, 2007). Rations were received twice daily at 8.00 and $15.00 \mathrm{hr}$. in equal parts, and water was freely available to all animals. During the collection period, feed and feces samples were dried at $60{ }^{\circ} \mathrm{C} / 24 \mathrm{hrs}$ in a hot air oven. At the end of the collection period, dried samples of feed and feces were analyzed according to the methods of AOAC (1996).

\section{B) Rumen liquor sampling and analysis:}

Rumen liquor samples were taken individually from animals using a stomach tube three times: before feeding (zero time), then at 3 and 6 hrs. post feeding at the end of the digestibility trials. Samples were filtered through four layers of surgical gauze to determined ruminal $\mathrm{pH}$ immediately using digital $\mathrm{pH}$ meter. Then, the samples were kept frozen for other ruminal parameters determination. Ruminal ammonia - N concentration was analyzed according to Conway (1963), while the total VFA s concentration was determined according to Warner (1964).

\section{Blood sampling and analysis:}

Blood samples were collected from the jugular vein of the animal at the end of the growth trials. The blood samples were centrifuged for 15 minutes at 3000 r. p. m., and then blood plasma was separated into polypropylene tube and stored. Total proteins and albumin were analyzed according to Doumas et al. (1971). Globulin value was calculated by the difference between total protein and albumin. Plasma total lipids mg/dl determined according to Zollner and Kirsch (1962). Plasma cholesterol mg/dl was determined according to Richmond (1973). Plasma Alanine Amino Transaminase (ALT) and Asperate Transaminase (AST) U/ml were determined according to Retiman and Frankel (1957).

Plasma uric acid mg/dl determined according to Barham and Trinder (1972).

\section{Economic efficiency:}

The economic efficiency in the present study was calculated from input - output analysis based on the total feed cost and price of the final gain in body weight. The values of economics efficiency was calculated as the net revenue per unit of total costs.

\section{6- Statistical Analysis:}

The obtained data were analyzed using the general linear model procedure of SAS(2001), using the following model :

$$
\mathrm{Yij}=\mu+\mathrm{Ti}+\mathrm{Eij}
$$

Where:

Yij $=$ Observed value of a given dependent variable. 
$\mu=$ Overall adjusted mean.

$\mathrm{Ti}=$ The effect of treatments.

Eij $=$ The experimental random error.

Significant differences among means were separated by Duncan's multiple range tests (Duncan, 1955).

\section{RESULTS AND DISCUSSION}

\section{Essential oils in dried Pomegranate pulp:}

The essential oils of the tested Pomegranate by-products are presented in Table (2). Dried pomegranate by-products contained numerous active metabolites such as allicin, linalool, myrcene, menthol, menthone, carvacrol and thymol. These results are in harmony with Chen et al. (2020) who announced that Pomegranate peels contained many bioactive compounds: phenolic acids, tannins and flavonoids .In contrast, Pomegranate pulp contains several important bioactive compounds which are beneficial in control of several health issues. The Pomegranate pulp contains 11 volatile organic compounds (1-hexanol, hexanal, $\beta$-caryophyllene, $\beta$-myrcene, 1-octanol, limonene, $\alpha$-terpineol, 2 hexenal, bergamotene, guaiacol and 3-hexen-1-ol) were found in pomegranate juices and seeds. Hexalin, 3-methyl butanal ,methyl, 1-methylethenyl,phenylacetaldehyde and benzene were common only in seeds. Guler and Gul (2012), Hernández et al. (2019).

Table (2): Essential oils in Pomegranate:

\begin{tabular}{llc}
\hline No. & Components & Content $(\%)$ \\
\hline 1 & Hexanol & 27.0 \\
2 & Hexanal & 14.5 \\
3 & Limonene & 27.2 \\
4 & $\alpha-$ Terpineol & 16.7 \\
5 & Cis -3- Hexanol & 3.5 \\
6 & 1-Nonanol & 1.3 \\
7 & 2-Ethyl hexanol & 4.6 \\
8 & Ethyl -2 methyl butanoate & 1.8 \\
9 & 6- Methyl -5-heptene - 2 & 0.9 \\
10 & Octanal & 1.9 \\
11 & $\beta$-caryophyllene & 2.8 \\
12 & $\beta$-cymene & 2.8 \\
\hline
\end{tabular}

\section{Vitamins content:}

Data of Table (3) that illustrated the vitamin contents of DPP cleared that it contained 15.12, 5.02, $0.496,0.395$ and $0.131 \mathrm{mg} / 100 \mathrm{~g}$ for vitamin $\mathrm{C}$, vitamin $\mathrm{E}$, vitamin A, vitamin B1, vitamin B2, respectively. The result values were in agreement with those established by (Rowayshed et al., 2013 and Omer et al., 2019). The presence of vitamins naturally in DPP is one of the most important factors that make DPP have an antioxidant, antimicrobial, and chemo preventive cancer properties. Huxley and Neil (2003). So, it could be mentioned that DPP considered a major source of vitamins.

Table (3): Vitamins content (mg/100g) of dried pomegranate by-products.

\begin{tabular}{lc}
\hline Vitamins & content $(\mathrm{mg} / 100 \mathrm{~g})$ \\
\hline Vitamin A & 0.496 \\
Vitamin E & 5.02 \\
Vitamin C & 15.12 \\
Vitamin B1 & 0.395 \\
Vitamin B2 & 0.131 \\
\hline
\end{tabular}




\section{Minerals content:}

Minerals of the tested Pomegranate by-product are presented in Table (4). The DPP contained 380, 149, 65, 172 and $71 \mathrm{mg} / 100 \mathrm{~g}$ of $\mathrm{Ca}, \mathrm{P}, \mathrm{Mg}, \mathrm{K}$ and $\mathrm{Na}$, respectively. Meanwhile, it contains 8.01, 1.32 and $1.18 \mathrm{mg} / 100 \mathrm{~g} \mathrm{DM}$ of Fe, Se and Zn, respectively.

These results demonstrated that DPB was a good source of nutritious macro and micro minerals (Omer et al., 2019).

Table (4): Minerals content (mg/100g) of dried pomegranate by-products.

\begin{tabular}{lc}
\hline Minerals & content $(\mathrm{mg} / 100 \mathrm{~g})$ \\
\hline Macro-elements & 380 \\
$\mathrm{Ca}$ & 149 \\
$\mathrm{P}$ & 172 \\
$\mathrm{~K}$ & 71 \\
$\mathrm{Na}$ & 65 \\
$\mathrm{Mg}$ & \\
$\mathrm{Micro}-$ elements & 8.01 \\
$\mathrm{Fe}$ & 1.32 \\
$\mathrm{Se}$ & 1.18 \\
$\mathrm{Zn}$ & \\
\hline
\end{tabular}

\section{Nutrients digestibility and nutritive value of the experimental rations:}

Result in Table (5) showed that the digestion coefficients of dry matter and organic matter of DPB rations showed a significantly differences $(\mathrm{P}<0.05)$ comparing with the control group. Adding DPB improved all nutrients digestibility than control by $(69-72.67)$ for $\mathrm{CP}$, $(52.13-58.40)$ for $\mathrm{CF}$, $(72.7-$ 75.24) for $\mathrm{EE}$ and $(80-83.1)$ for NFE. Results showed that there was a significantly $(\mathrm{P}<0.05)$ increase with lambs fed $20 \mathrm{~g} / \mathrm{head} /$ day of pomegranate pulp (R3) and with lambs fed $10 \mathrm{~g} / \mathrm{head} / \mathrm{day} \mathrm{R} 1$, followed by animals fed $30 \mathrm{~g} / \mathrm{head} /$ day of pomegranate by- products $\mathrm{R} 4$ compared to the control group.

These results are in harmony with those observed by Sadq et al . (2016) that the dry matter digestibility (DMD), crude protein digestibility (CPD), crude fiber digestibility (CFD) and nitrogen free extract digestibility (NFED) were significantly $(\mathrm{P}<0.05)$ higher in lambs fed $1 \%$ and $2 \%$ Pomegranate Peel compared to $3 \%$ and control group.

Table (5): Nutrient digestibility and nutritive value (\% DM basis) of the experiment rations.

\begin{tabular}{lccccc}
\hline & \multicolumn{5}{c}{ Experimental ration } \\
\cline { 2 - 5 } Item & $\mathrm{R} 1$ & $\mathrm{R} 2$ & $\mathrm{R} 3$ & $\mathrm{R} 4$ & SEM \\
\hline $\mathrm{DM}$ & $74.20^{\mathrm{c}}$ & $75.60^{\mathrm{b}}$ & $76.40^{\mathrm{a}}$ & $75.82^{\mathrm{b}}$ & 1.28 \\
$\mathrm{OM}$ & $75.60^{\mathrm{b}}$ & $78.42^{\mathrm{a}}$ & $78.80^{\mathrm{a}}$ & $76.90^{\mathrm{ab}}$ & 1.24 \\
$\mathrm{CP}$ & $69.00^{\mathrm{b}}$ & $72.03^{\mathrm{a}}$ & $72.67^{\mathrm{a}}$ & $72^{\mathrm{a}}$ & 0.90 \\
$\mathrm{EE}$ & $72.7^{\mathrm{b}}$ & $75.24^{\mathrm{a}}$ & $75.20^{\mathrm{a}}$ & $74.16^{\mathrm{a}}$ & 1.08 \\
$\mathrm{CF}$ & $52.13^{\mathrm{b}}$ & $57.42^{\mathrm{a}}$ & $58.40^{\mathrm{a}}$ & $57.67^{\mathrm{a}}$ & 1.44 \\
$\mathrm{NFE}$ & $80.00^{\mathrm{b}}$ & $82.90^{\mathrm{a}}$ & $83.10^{\mathrm{a}}$ & $82.72^{\mathrm{a}}$ & 1.52 \\
$\mathrm{TDN}$ & $68.88^{\mathrm{b}}$ & $71.83^{\mathrm{a}}$ & $72.16^{\mathrm{a}}$ & $71.69^{\mathrm{a}}$ & 0.91 \\
DCP & $10.90^{\mathrm{b}}$ & $11.37^{\mathrm{a}}$ & $11.48^{\mathrm{a}}$ & $11.37^{\mathrm{a}}$ & 0.27 \\
\hline a,b,c: means on the same row with different superscript are significantly different $(p<0.05)$. &
\end{tabular}

The TDN value for control ration was significantly $(\mathrm{p}<0.05)$ lower than all the tested groups. The DCP values ranged between 11.37 to 11.48 for tested rations while it was decreased to $10.90 \%$ for control group.

Saaed et al. (2018) recorded that addition of pomegranate peels have a positive effect on efficiency of energy utilization and improved bacterial growth in rumen, enhanced production of microbial protein and increase volatile fatty acids or indirectly inhibited the phagocytosis of protozo to bacterial cells. 


\section{Rumen parameters:}

Results in Table (6) showed no significant between the mean values of ruminal $\mathrm{pH}$ value and Ammonia - N concentration. Regarding the effect of sampling time on $\mathrm{NH}_{3}-\mathrm{N}$ concentration it may be noticed that the ruminal $\mathrm{NH}_{3}$-Nconcentration was increased at $3 \mathrm{hrs}$. post feeding, but it decreased at $6 \mathrm{hrs}$ post feeding for all treatments.

The volatile fatty acids concentrations (meq $/ 100 \mathrm{ml}$ ) of rumen fluid were significantly $(\mathrm{p}<0.05$ ) higher for R3, R2 and R4, respectively than the control group. Increasing in volatile fatty acids concentration of DPB rations compared to the control group could also due to the increase in OM digestibility within the DPB groups.

Table (6): Effect of adding drying pomegranate by-products to rations on some rumen parameters.

\begin{tabular}{|c|c|c|c|c|c|c|}
\hline \multirow{2}{*}{ Item } & \multicolumn{6}{|c|}{ Experimental rations } \\
\hline & Time & R1 & R2 & R3 & $\mathrm{R} 4$ & SEM \\
\hline \multirow[t]{4}{*}{$\mathrm{pH}$ values } & 0 & $6.40^{\mathrm{b}}$ & $7.0^{\mathrm{a}}$ & $7.10^{\mathrm{a}}$ & $7.20^{\mathrm{a}}$ & - \\
\hline & 3 & $5.70^{\mathrm{b}}$ & $5.70^{\mathrm{b}}$ & $6.20^{\mathrm{a}}$ & $6.22^{\mathrm{a}}$ & - \\
\hline & 6 & 6.50 & 6.50 & 6.58 & 6.62 & - \\
\hline & Mean & 6.20 & 6.40 & 6.63 & 6.68 & 0.341 \\
\hline \multirow{4}{*}{$\begin{array}{l}\text { Ammonia }-\mathrm{N} \\
(\mathrm{mg} / 100 \mathrm{ml})\end{array}$} & 0 & 23.2 & 24.2 & 25.6 & 23.6 & - \\
\hline & 3 & 35.8 & 36.4 & 36.8 & 36.2 & - \\
\hline & 6 & 29.7 & 31.4 & 32.2 & 31.2 & - \\
\hline & Mean & 29.6 & 30.67 & 31.53 & 30.33 & 2.93 \\
\hline \multirow{4}{*}{$\begin{array}{l}\text { Total VFAs } \\
(\mathrm{meq} / 100 \mathrm{ml})\end{array}$} & 0 & $6.9^{\mathrm{b}}$ & $8.3^{\mathrm{a}}$ & $8.5^{\mathrm{a}}$ & $8.4^{\mathrm{a}}$ & - \\
\hline & 3 & $10.1^{\mathrm{b}}$ & $10.6^{\mathrm{a}}$ & $11.5^{\mathrm{a}}$ & $10.2^{\mathrm{b}}$ & - \\
\hline & 6 & $8.9^{\mathrm{b}}$ & $9.7^{\mathrm{a}}$ & $10^{\mathrm{a}}$ & $9.6^{\mathrm{a}}$ & - \\
\hline & Mean & $8.63^{b}$ & $9.53^{\mathrm{a}}$ & $10^{\mathrm{a}}$ & $9.4^{\mathrm{a}}$ & 1.73 \\
\hline
\end{tabular}

$a, b, c:$ means on the same row with different superscript are significantly different $(P<0.05)$.

\section{Blood parameters:}

Data in Table (7) showed no significant difference detected for uric acid, ALT and AST among all the experimental rations. But dried Pomegranate by-products decreased cholesterol level in plasma, with the highest effect (162 mg / dl) for R3 followed by R2 and R4 compared to the control group. Also, decreased total lipid and increase total protein with significant $(\mathrm{P}<0.05)$ differences comparing with the control group. Also, globulin level increased significantly $(\mathrm{P}<0.05)$ comparing with the control group. The highest value was for R3 followed byR2 and R4. This increase in globulin is because of that dried Pomegranate pulp contained steroidal flavonoid terpens which stimulate the conventional secretion of cortisone. Seventy percent from this cortisone bind with globulin El-Elaime (2007).

Table (7): Blood plasma constituents recorded for lambs fed the experimental rations.

\begin{tabular}{lllllllll}
\hline Item & $\begin{array}{l}\text { Total } \\
\text { Protein }\end{array}$ & Albumin & Globulin & $\begin{array}{l}\text { Total } \\
\text { lipid }\end{array}$ & Cholesterol & $\begin{array}{l}\text { Uric } \\
\text { acid }\end{array}$ & ALT & AST \\
\hline R1 & $7.0^{\mathrm{b}}$ & 3.4 & $3.6^{\mathrm{b}}$ & $328^{\mathrm{a}}$ & $188^{\mathrm{a}}$ & 1.76 & 21.0 & 39.0 \\
R2 & $8.0^{\mathrm{a}}$ & 3.6 & $4.4^{\mathrm{a}}$ & $306^{\mathrm{c}}$ & $162^{\mathrm{c}}$ & 1.71 & 20.4 & 37.2 \\
R3 & $7.8^{\mathrm{a}}$ & 3.5 & $4.3^{\mathrm{a}}$ & $302^{\mathrm{d}}$ & $155^{\mathrm{d}}$ & 1.70 & 20.0 & 38.1 \\
R4 & $7.9^{\mathrm{a}}$ & 3.5 & $4.4^{\mathrm{a}}$ & $309^{\mathrm{b}}$ & $169^{\mathrm{b}}$ & 1.71 & 21.2 & 38.7 \\
SEM & 0.130 & 0.226 & 0.108 & 0.912 & 1.89 & 0.126 & 0.341 & 0.372 \\
\hline
\end{tabular}

a,b,c: means on the same row with different superscript are significantly different $(P<0.05)$. 
Egyptian J. Nutrition and Feeds (2021)

Live weight gain and feed conversion of lambs fed the experimental rations:

Data in Table (8) illustrate the live weight gain and feed conversion of lambs fed the experimental rations.

Table (8): Dry matter intake, live weight gain and feed efficiency of lambs fed the experimental rations.

\begin{tabular}{lccccc}
\hline Item & \multicolumn{5}{c}{ Experimental ration } \\
\cline { 2 - 6 } & $\mathrm{R} 1$ & $\mathrm{R} 2$ & $\mathrm{R} 3$ & $\mathrm{R} 4$ & $\mathrm{SEM}$ \\
\hline Initial wt. $(\mathrm{kg})$ & 28.20 & 28.1 & 28.4 & 28.5 & 0.120 \\
Final wt. $(\mathrm{kg})$ & 46.20 & 49.2 & 49.4 & 47.0 & 0.640 \\
Total gain $(\mathrm{kg})$ & $18^{\mathrm{c}}$ & $21.1^{\mathrm{a}}$ & $21^{\mathrm{a}}$ & $19^{\mathrm{b}}$ & 0.167 \\
Daily gain $(\mathrm{g})$ & $150^{\mathrm{c}}$ & $175.8^{\mathrm{a}}$ & $175^{\mathrm{a}}$ & $158.3^{\mathrm{b}}$ & 1.830 \\
Feed intake /h/d & & & & & \\
DMI, kg & 0.985 & 0.980 & 0.960 & 0.945 & - \\
TDN, $\mathrm{kg}$ & 0.678 & 0.704 & 0.698 & 0.694 & - \\
DCP, g & 107 & 111 & 110 & 107 & - \\
Feed conversion & & & & & \\
DM/gain, $\mathrm{kg} / \mathrm{kg}$ & 6.57 & 5.58 & 5.49 & 5.97 & - \\
TDN/gain, $\mathrm{kg} / \mathrm{kg}$ & 4.52 & 4.01 & 3.99 & 4.38 & - \\
DCP/gain, $\mathrm{kg} / \mathrm{kg}$ & 0.71 & 0.63 & 0.63 & 0.68 & - \\
\hline ab,c: means on the same row with different superscript are significantly different $(P<0.05$ & &
\end{tabular}

Pomegranate by-products significantly $(\mathrm{P}<0.05$ ) improved the daily gain by175.8 g, $175 \mathrm{~g}, 158.3 \mathrm{~g}$ for R2, R3, R4, respectively compared to the control group by $150 \mathrm{~g}$.

Feed conversion was enhanced in all treated groups than control group. These results support the thought that low level of Pomegranate by-products supplements improved weight gain and decreased feed conversion.

These results in agreement with Aerts et al. (1999), Makkar (2003), Hussein et al. (2013) and Sadq et al. (2016) who demonstrated that adding $1 \%$ or $2 \%$ pomegranate peel significantly ( $\mathrm{P}<0.05)$ improved weight gain , final body weight, DMI and feed conversion compared to lambs fed $4 \%$ and control group.

The prevalence of low level of DPB improved growth of lambs due to existence of tannin decreased ruminal ammonia concentration which protected protein from degradation in the rumen Ghiasi et al. (2017) and Saaed et al. (2018).

In contrast, Shabtay et al. (2008) and Hussein et al. (2013) determined that Pomegranate peel improved immune function because of their anti-oxidative and immune-modulator properties , which could benefit health of lambs and calves performance .

However, high levels of Pemogranate (R4) caused high concentrations of tannins, these reduced feed intake, digestibility of protein and carbohydrates and animal performance due to their negative effects on palatability and digestion. Perevolotsky et al. (1993)

\section{Economic evaluation:}

Data in Table (9) showed that adding Pomegranate by-products significantly ( $\mathrm{p}<0.05$ ) increased the economic efficiency for growing lambs. The effect was the highest for R2and R3followed by R4 compared to control group.

Referring to the obtained results, it could be recommended that using $10-20 \mathrm{~g} / \mathrm{head} /$ day of dried Pomegranate by-products as feed additive in growing lambs ration exhibited positive effect on productive performance of Barki lambs and improved weight gain, feed conversion and economic efficiency. 
Table (9): Economic evaluation of the experimental ration.

\begin{tabular}{|c|c|c|c|c|c|}
\hline \multirow[t]{2}{*}{ Item } & \multicolumn{4}{|c|}{ Experimental ration } & \multirow[b]{2}{*}{ \pm SEM } \\
\hline & R1 & R2 & R3 & $\mathrm{R} 4$ & \\
\hline Total weight gain obtained (kg) & $18^{\mathrm{c}}$ & $21.1^{\mathrm{a}}$ & $21^{\mathrm{a}}$ & $19^{\mathrm{b}}$ & 0.221 \\
\hline Consumed DM (kg) to produce & 118.2 & 117.6 & 115.2 & 113.4 & - \\
\hline Feed cost ( LE) for Total weight gain & 472.8 & 478.8 & 477.6 & 478.8 & - \\
\hline Total revenue $(\mathrm{LE})$ & 1080 & 1266 & 1260 & 1140 & - \\
\hline Net revenue ${ }^{* *}(\mathrm{LE})$ & 607.2 & 787.2 & 782.4 & 661.2 & - \\
\hline Economic efficiency ${ }^{* *} *$ & 1.28 & 1.64 & 1.64 & 1.38 & - \\
\hline Relative Economic efficiency & 100 & 128.1 & 128.1 & 107.8 & - \\
\hline
\end{tabular}

$a, b, c:$ means on the same row with different superscript are significantly different $(p<0.05)$

Total revenue $*=$ Total weight gain $*$ price of $\mathrm{kg}$ live weight gain $(60 \mathrm{LE})$

Net revenue $* *=$ Total revenue - Feed cost for total weight gain.

Market prices were as follow: concentrate was 4500LE / Ton, alfalfa hay was 3000LE /Ton. dried pomegranate byproduct was $700 \mathrm{LE} / \mathrm{Ton}$

Economic efficiency ${ }^{* * *}=($ Net revenue $) /($ Total feed cost $)$

\section{REFERENCES}

Aerts, R.J.; T.N. Barry and W.C McNab (1999). Polyphenols and agriculture: Beneficial Eefects of proanthocyanidins in forages. Agriculture, Ecosystems \& Environment, 75: 1-12.

AOAC (1996). Association of Official Analytical Chemists. Official Methods of Analysis 13th Ed. Washington, D. C, USA.

AOAC (2005). Association of Officiating Analytical Chemists. Official Method of Analysis. 18th Edition, Washington DC, Method 935.14 and 992.24.

Barham,D. and A.Trinder (1972). Determination of plasma uric acid .Analyst, 97: 142.

Bkeer ,M.R.;M.M.El-Attrouny and A.M .Abdelatty (2021) .Effect of dietary pomegranate peel (Punica granatum L.) and Aloeveragel (Aloe barbadensis miller) supplementation on testicular antioxidant biomarkers and spermatogenesis enzymes in mature V-Line rabbit bucks. Journal of Animal Physiology and Animal Nutrition,105:175-182.

Brown, M.W. and J.H. Watkinson (1977). An automated fluorometric method for the determination of nano-gram quantities of selenium. Anal. Chem.Acta, 89:29-35

Chen, J.; C. Liao;C. Ouyang; I. Kahramanoğlu and L. Mingxi (2020). Antimicrobial activity of pomegranate peel and its applications on food preservation. Journal of food Quality, review article, 20 $: 1-8$.

Conway, E.F.( 1963). Modification analysis and volumetric error .Rev. Ed. Look Wood, London.

Doumas , B.; W. Wabson and H. Biggs ( 1971). Albumin standard and measurement of serum with bromocresol green. Clin. Chem. Acta., 32:81.

Duncan, D. B. (1955) . Multiple tests . Biometrics .11: $1-42$.

Elelaime ,R.R. (2007).Performance of goats fed certain medicinal herbs with reference to milk production and its manufacture. Ph.D. Thesis, Faculty of Agric., Cairo Univ., Egypt.

Guler, Z. and E. Gul ( 2012 ). Volatile organic compounds in the ariljuices and seeds fromselected five pomegranate (Punica granatum L.) cultivars. International Journal of Food Properties , 20:281- 293.

Hernández,E.;M.L. Marina and M. C. García,( 2019). Extraction and identification by high resolution mass spectrometry of bioactive substances in different extracts obtained from pomegranate peel. Journal of Chromatography A, 7: 82-92. 
Hussein, S.A.M. and T.A.Shujaa(2013). The effect of using different ratios of pomegranate peels in performance and digestibilities in Awassi lambs. J.Tikrit University Agric. Sci., 13: 52-62.

Huxley, R.R. and H. Neil (2003). The relationship between dietary flavonol intake and coronary heart disease mortality: a meta-analysis of prospective cohortm studies. Europ. J. Clinical Nutr., 57:904908

Khalaf, H. A.;Arafat, E. A. and F. M. Ghoneim (2019). A histological, immune histochemical and biochemical study of the effects of pomegranate peel extracts on gibberellic acid induced oxidative stress in adult rat testes. Biotechnic \& Histochemistry, 94(8): 569-582.

Kraul, M. (1966). Semi-automated determination of phospholipids. Clin.Chem.Acta, 13:442-446.

Leth, T. and H. Sondergaro (1983). Biological activity of all-trance tocopherol determined by three different rat bioassays. Int. J. Vit. Nutr. Res., 53:297-311

Makkar, H.P.S. (2003) Effects and fate of tannins in ruminant animals, adaptation to tannins and strategies to overcome detrimental effects of feeding tannin-rich feeds. Small Ruminant Res., 49:241256.

NRC (2007). National Research Council. Nutrient Requirement of Domestic Animal. The Nutrition Requirements of Dairy Cattle.7th rev. ed. National Academy press. Washington, DC, USA.

Omer, H.A.A; S.S. Abdel-Magidand I.M. Awadalla (2019). Nutritional and chemical evaluation of dried pomegranate (Punica granatum L.)peels and studying the impact of level of inclusion in ration formulation on productive performance of growing Ossimi lambs. Bulletin of the National Research Center, 43: 2-10.

Perevolotsky,A.; A.Brosh; O.Ehrlich; M.Gutman; Z.Henkin and Z. Holzer (1993). Nutritional value of common oak (Quercus calliprinos) browse as fodder for goats: Experimental results in ecological perspective. Small Ruminant Research, 11: 95-106.

Retiman, A. and S. Frankel (1957) .A Colorimetric method for the Determination of Plasma Glutamic Oxaloacetic and Glutamic Pyruvic Transaminase. Amer J. Clin. Path., 28:56 - 63.

Richmond, W. (1973). Determination of plasma cholesterol .Clin. Chem., 19: 1350.

Rowayshed, G.;A. Salama;M. Abul-Fadl; S. Akila-Hamza and E.A. Mohamed (2013). Nutritional and chemical evaluation for pomegranate (Punica granatum $L$.) fruit peel and seeds powders by products. Middle East J.Appl Sci., 4:169-179

Sadq, S.M.; O.M.D. Ramzi; H.J.Hamasalim and K.A. Ahmed (2016). Growth performance and digestibility in karadi lambs receiving different levels of pomegranate peels. Open J. Anim. Sci.; 6: 16-23.

Saeed, A.; E.Abdulridha; Z. Ali and M. Mohsen (2018). Effect of addition of different levels of pomegranate peel powder to concentrate diet on productive performance of Awassi lambs. AlQadisiyah Journal of Veterinary Medicine Sciences, 16: 35-43.

SAS (2001). SAS Users Guide: Statistics. Version 5 Edition. SAS Inc., Carry, NC.

Shabtay,A.;H. Eitam; Y.Tadmor; A.Orlov; A. Meir; P. Weinberg;Z.G. Weinberg;Y. Chen; A. Brosh; I. Izhaki and Z.Kerem (2008). Nutritive and anti-oxidative potential of fresh and stored pomegranate industrial byproduct as novel beef cattle feed. J.Agric. Food Chem., 56:10063-10070

Warner , A.C.I. (1964). Production of volatile fatty acids in the rumen methods of measurement . Abst.and Rev., 34: 339.

Zollner, N. and K. Kirsch (1962). Determination of plasma total lipids. Exp. Med., 135: 545.

Zeweil, H. S.;Elnagar, S.;Zahran, S. M.;Ahmed, M. H. and Y.El-Gindy (2013). Pomegranate peel as a natural antioxidant boosts bucks' fertility under Egyptian summer conditions. World Rabbit Science, 21(1):33-39. 
تأثير اضافة مستويات مختلفة من مخلفات تصنيع الرمان كاضافات علفية على الاداء الأنتاجى لحملان أغنام البرقى النامية

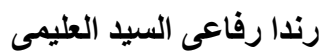 \\ قسم الانتاج الحيوانى ـ كلية النزراعة - جامعة الثقاهرة- مصر.
}

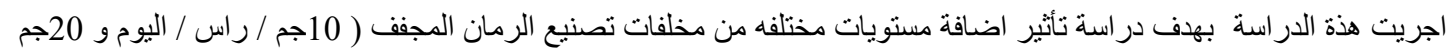

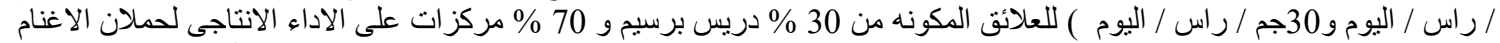

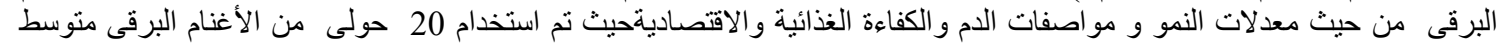

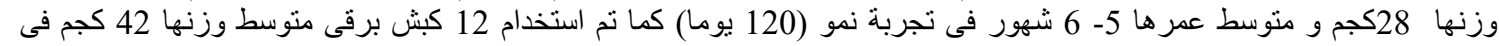

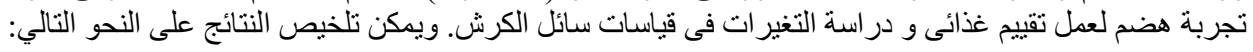

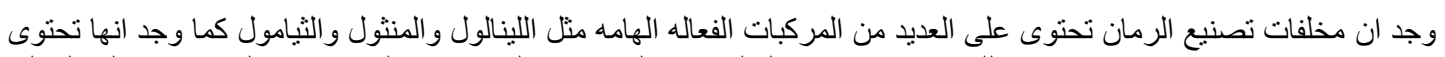

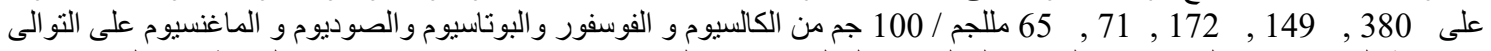

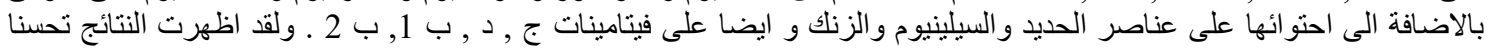

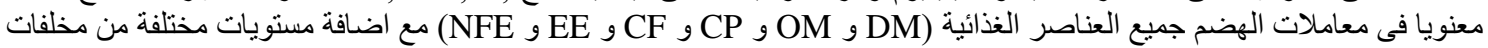

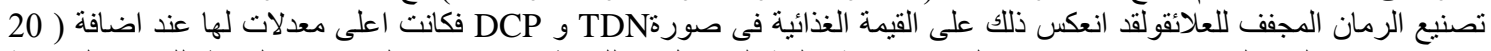

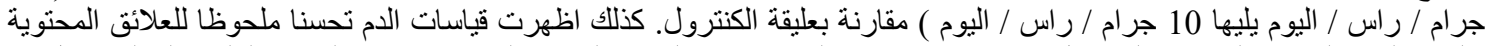

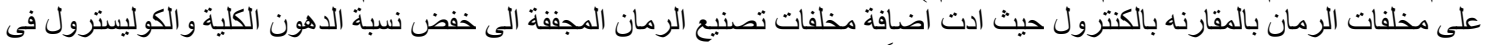

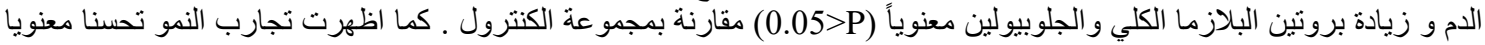

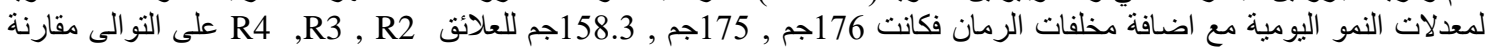

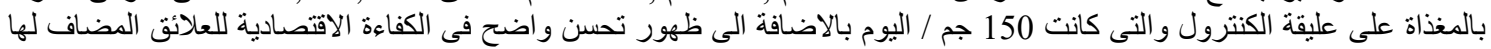

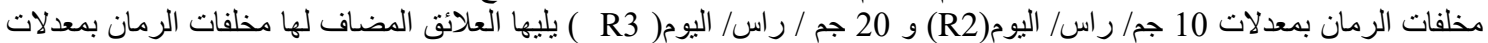

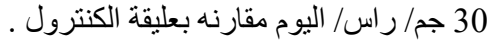

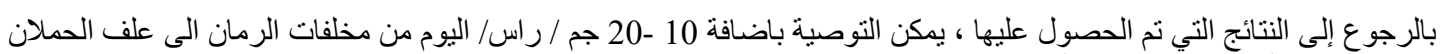

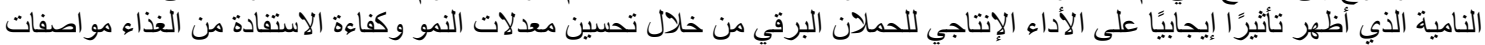

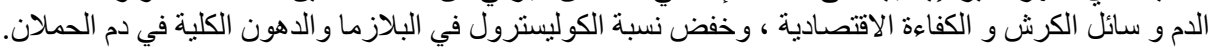

